\title{
Miranda
}

Revue pluridisciplinaire du monde anglophone /

Multidisciplinary peer-reviewed journal on the English-

speaking world

$12 \mid 2016$

Mapping gender. Old images ; new figures

\section{Conference Report: Le studio Hammer, laboratoire de l'horreur moderne}

Paris, (France), June 12-14, 2016

Conference organized by Mélanie Boissonneau, Gilles Menegaldo and Anne-Marie Paquet-Deyris

David Roche

\section{OpenEdition \\ Journals}

\section{Electronic version}

URL: http://journals.openedition.org/miranda/8195

DOI: $10.4000 /$ miranda.8195

ISSN: 2108-6559

Publisher

Université Toulouse - Jean Jaurès

\section{Electronic reference}

David Roche, "Conference Report: Le studio Hammer, laboratoire de l'horreur moderne ", Miranda

[Online], 12 | 2016, Online since 29 February 2016, connection on 16 February 2021. URL: http:// journals.openedition.org/miranda/8195 ; DOI: https://doi.org/10.4000/miranda.8195

This text was automatically generated on 16 February 2021.

\section{(c) (i) $(9)$}

Miranda is licensed under a Creative Commons Attribution-NonCommercial-NoDerivatives 4.0 International License. 


\section{Conference Report: Le studio Hammer, laboratoire de l'horreur moderne}

Paris, (France), June 12-14, 2016

Conference organized by Mélanie Boissonneau, Gilles Menegaldo and

Anne-Marie Paquet-Deyris

David Roche

1 This exciting conference ${ }^{1}$ was the first entirely devoted to the British exploitation film studio in France. Though the studio had existed since the mid-1940s (after a few productions in the mid-1930s), it gained notoriety in the mid-1950s with a series of readaptations of classic Gothic novels previously adapted for the theater in the 1920s and by Universal studios in the 1930s. Hammer Films is mostly famous for the films of Terence Fisher, who has gained the status of auteur with The Curse of Frankenstein (1957), Horror of Dracula (1958), The Hound of the Baskervilles (1959), The Curse of the Werewolf (1961), The Gorgon (1964), Dracula: Prince of Darkness (1966) and The Devil Rides Out (1968), but the studio produced a number of other worthy movies, including The Quatermass Xperiment (Val Guest, 1955), Plague of the Zombies (John Gilling, 1966), Quatermass and the Pit (Roy Ward Baker, 1967), The Vampire Lovers (Baker, 1970), Twins of Evil (John Hough, 1971) and Dr. Jekyll and Sister Hyde (Baker, 1971). After ceasing production in 1979, interestingly enough with a remake of Hitchcock's 1938 The Lady Vanishes (Anthony Page), the studio rose from the grave in the late 2000s, producing the remakes Let Me In (Matt Reeves, 2010) and The Woman in Black (James Watkins, 2012); these films were box office hits, but owe very little to Hammer aesthetics, as Sophie Mantrant (Université Strasbourg) concluded.

2 The spirit of the conference endeavored to combine passionate celebration and scholarly reflection. It was organized by Mélanie Boissonneau (IRCAV, Université Paris 3), Gilles Menegaldo (Université de Poitiers) and Anne-Marie Paquet-Deyris (Université Paris Ouest Nanterre), lasted three days and was held in three separate venues (Paris 3, Paris Ouest and the Cité Universitaire). On Wednesday night, Horror of Dracula was 
screened at Cinéma Le Grand Action, following a discussion with the conference organizers, as well as filmmaker Marc Caro, film critic Gérard Lenne and Hammer actress Caroline Munro. Speakers found out about Christopher Lee's death the next morning. ${ }^{2}$ Though greatly saddened, everyone was unanimous in praising the actor's career, which had spanned over five decades and included such notable films as The Wicker Man (Robin Hardy, 1973), The Man with the Golden Gun (Guy Hamilton, 1974) and The Lord of the Rings (Peter Jackson, 2001-2003); those lucky enough to have met or even known the actor shared fond memories over dinner on Thursday night.

3 The conference featured two keynote conferences and a panel of scholars from De Montfort University's Cinema And Television History (CATH) Research Centre in Leicester, where the Hammer archive is located. On Wednesday morning, Ian Conrich (University of Southern Australia) focused on the 1970s, a decade when Hammer films became increasingly hybrid in order to compete with other independent productions, drawing on the success of Hong Kong films, spaghetti westerns, sexploitation, blaxploitation and even the James Bond franchise in films like Satanic Rites of Dracula (Alan Gibson, 1973), Captain Kronos: Vampire Hunter (1974) and The Legend of the Seven Golden Vampires (Roy Ward Baker and Cheh Chang, 1974). On Thursday morning, JeanFrançois Baillon (Université Bordeaux Montaigne) examined a cycle of lesser-known Hammer films, thrillers that were largely influenced by the success of Les Diaboliques (Clouzot, 1955) and Psycho (Hitchcock, 1960), including Maniac (Michael Carreras, 1963), Hysteria (Freddie Francis, 1965), Fanatic (Silvio Narizzano, 1965) and The Nanny (Seth Holt, 1965). Both Baillon and Conrich identified these films as sites where multiple influences converged. Friday morning opened with Steve Chibnall's presentation of the Hammer Script Archive at De Monfort, was followed by Ian Hunter's talk concerning the rehabilitation of Hammer Films in British film history as a studio whose range was much broader than horror, and ended with Matt Jones's stimulating analysis of the script of the unmade remake of The Day the Earth Caught Fire.

4 The thirty other talks offered a wide range of approaches. Film history: Robert J.E. Simpson (Diabolique Magazine $e^{3}$ emphasized the diversity of early Hammer and the part played by William Hinds in the studio's development, while Nicolas Stanzick, author of Dans les griffes de la Hammer (2010), accounted for the reception of Hammer films in 1960s France. Cultural, gender and post-colonial studies: Xavier Daverat (Université de Bordeaux) focused on the treatment of class, Christian Chelebourg on the monstrousfeminine in John Gilling's The Reptile (1966), and Gaïd Girard (Université Bretagne Occidentale) on the inscription of misogyny and the crisis of British masculinity in the final scenes of Quatermass and the Pit; Rehan Hyder suggested that The Mummy (Fisher, 1959) was ultimately a more ideologically ambiguous film than The Stranglers of Bombay (Fisher, 1959). Acting and star studies: Hélène Valmary (Université de Caen BasseNormandie) attempted to describe the dynamics at work in the Cushing/Lee duo, while Jean-Marie Samocki (Université Paris Est) foregrounded the way the films featuring Peter Cushing enable the viewer to get a sense of the mortality through the ageing actor. Film aesthetics: Pierre Jailloux (Université Grenoble) insisted on the importance of blood as a color, while Raphaëlle Costa de Beauregard (Université Toulouse Jean Jaurès) explored the color schemes used in Curse of Frankenstein; Cécile Carayol (Université de Rouen) focused on the influences of Hollywood film music conventions on Hammer films, Philippe Marion (Université de Louvain) on the relationship between music and staging, and Florence Chéron (Université Paris 8) on how the use of the same props and studios contributes to a specific Hammer style; Isabelle Labrouillère (ESAV, 
Toulouse) brilliantly demonstrated how the presence of Rembrandt's The Anatomy Lesson of Dr. Nicolaes (1632) in Curse of Frankenstein produces a metafictional discourse whereby the film distances itself from the legacy of James Whale. Some talks sought to foreground other traditions at work in Hammer films: Ruth Heholt (Falmouth University) argued the case for a specific Cornish Gothic in The Plague of the Zombies and The Reptile, while Jean-Michel Durafour (Université Lille 3) explored various influences on Fisher's compositions.

5 The sheer range of the talks was immensely satisfying and largely confirmed the importance of the studio and its productions in British film history and in the history of the horror genre. But one thing did leave me with a sense of unfinished business: the question of Hammer's modernity. The conference left me with the impression that Hammer horror movies were by no means instances of modern horror so much as upgradings of classical horror. Speakers repeatedly singled out the extreme closeup of Christopher Lee in Horror of Dracula as the epitome of Hammer's modernity because of the blood, and the conflation of the beastly and the erotic. But in that case, Hammer was only modern for a few fears, that is till movies like Psycho (Hitchcock, 1960), Blood Feast (Herschell Gordon Lewis, 1963), Night of the Living Dead (George A. Romero, 1968) and Rosemary's Baby (Roman Polanski, 1968) set the standards for the modern horror movie. The experimentation at work in Hammer horror films represents, I would argue, an attempt to preserve a dying tradition rather than to create something new. The use of color is not enough to warrant the term "modern" or "revolutionary." It was little more than the embalming fluid used to resurrect a dead genre and mummify it in the process. This, I would suggest, is precisely what makes these films so endearing: the feeling that they are fighting a losing battle against their own mortality.

\section{NOTES}

1. http://arweenm.wix.com/hammer. Accessed on 12/11/2015.

2. See https://audioboom.com/boos/3272665-christopher-lee-s-death-announced-as-hammerconference-opened. Accessed on 12/11/2015.

3. http://diaboliquemagazine.com. Accessed on 12/11/2015.

\section{INDEX}

Keywords: Hammer Films, British cinema, horror cinema, film studies Subjects: Film 
AUTHORS

DAVID ROCHE

Professor of Film Studies

Université Toulouse Jean Jaurès

mudrock@neuf.fr 